Mubanga E. Kashoki

Anthony Ngubo

Naomi Quinn

David Wiley

Sylvia Winter

Michael Cole

Jehenne Teilhet

Jean Borgatti

Barbara Hampton

John Gartley

\section{TENTATIVE PAPERS}

Thomas E. Jones

Carolyn Sargent

James A. Sackey

Kathryn Tidrick
The Foreign Researcher in Africa

Southern Africa

Local Level Economic Systems

Contemporary Religion

African Literature: The Poet in Africa: Thematic Symposium

The Consequences of Literacy in Africa: Thematic

Symposium

African Forms of Communication in the New World

Masquerades as a Traditional Form of Media Reinforcement for African Value Systems

Music in Urban Africa

Educational Uses of Media in Africa

\author{
"Ivorian Educational Television" \\ "Community Health in Africa" \\ "Continuity and Change: From Traditional to Westem-type \\ Medical Care in Ghana" \\ "Relationship between the Masai and the British Officials"
}

\title{
LETTER/APPOINTMENT OF PROF. E. MPHAHLELE
}

The Executive Secretary

07-8-1978

African Studies Association

Brandeis University

Waltham, Mass. 02154

U.S.A.

Dear Mr. Duffy

\section{APPOINTMENT OF PROF. E. MPHAHLELE}

With reference to your letter of 17 May 1978 I wish to advise you by direction of the Honourable W.A. Cruywagen, Minister of Education and Training of the Republic of South Africa that it would appear that you have based your protest on the erroneous assumption that the position of Professor in English at the University of the North has been offered to Dr. Mphahlele. This is not correct. Dr. Mphahlele has never been offered this position; neither by the University, nor by the Government.

I wish to assure you that the decision not to appoint Dr. Mphahlele to the position for which he had applied, was motivated solely by a sense of responsibility to the people concerned after careful consideration had been given to all the information and facts at my Minister's disposal. I have no doubt that the University has accepted my Minister's ruling in that light. 